Research Article

\title{
Geospatial Assessment of Site Suitability for Tilapia Cage Culture in Cross River State, Nigeria
}

\author{
Chukwudi Njoku ${ }^{1 *}$, Inyang Etim-Inyang ${ }^{2}$, Prince-Charles Itu ${ }^{1}$ and Arinze Uzoezie ${ }^{1}$ \\ ${ }^{1}$ University of Calabar, Nigeria; ${ }^{2}$ Challawa River Nigeria Limited, Nigeria.
}

\begin{abstract}
This study applies geospatial technology to determine the most suitable sites for the development of Tilapia cage culture in Cross River State, Nigeria. A Geographic Information Systems (GIS) Multi-Criteria Evaluation (MCE) technique was applied using secondary data and considering factors such as elevation, land-use, accessibility (roads), river width, population density, distance from anthropogenic activities and climatic variables (temperature and rainfall intensity). The criteria and threshold for siting Tilapia cage culture were adopted from previous studies and processes such as classification, buffering, interpolation, slope analyses, single and multiple Structured Query Languages (SQL). The analyses divulged 23 river sites that are suitable for setting up Tilapia cage culture in the State, all covering a total of 18.44 square kilometers (4.49 percent) of the water bodies in the area. The result is an essential decision-making tool for individuals and organizations in agro-business, fishermen and especially. It can also be key to stimulating sustainable water resource use and management. The study illuminates the need for site suitability assessment by small and large-scale aquaculture farmers and the application of geospatial tools and findings for real-world decision making in Nigeria's aquaculture and agriculture sector.

Received | May 14, 2021; Accepted | October 30, 2021; Published | February 17, 2022

*Correspondence | Chukwudi Njoku, University of Calabar, Nigeria; Email: chukwudi.njokupg@gmail.com

Citation | Njoku, C., I. Etim-Inyang, P.C. Itu and A. Uzoezie. 2022. Geospatial assessment of site suitability for tilapia cage culture in cross river State, Nigeria. Sarhad Journal of Agriculture, 38(2): 456-469.

DOI | https://dx.doi.org/10.17582/journal.sja/2022/38.2.456.469

Keywords | Aquaculture, Tilapia cage culture, Site suitability, Geographic information systems, Agriculture
\end{abstract}

\section{Intoduction}

A quaculture is the fastest growing animal food production sector in the world, and is assuming the main provider of aquatic animal food for human consumption (Ottinger et al., 2016). Aquaculture and wild capture fisheries supply the world with about 148 million tons of fish valued at US\$217.5 billion (GET, 2013). It accounted for 25.7 percent of the total fish supply for human consumption in the year 2000. This increased to 46.8 percent in the year 2016 (FAO, 2018). The production capacity of aquaculture varies from country to country, based on available technologies, specialties and management plans put in place. China is the largest producer of aquaculture products in the world (FAO, 2014). The other three countries that follow China in the rank are India, $\mathrm{Vi}^{-}$ etnam and Indonesia.

Notwithstanding the expansion in aquaculture production, in comparison to other sectors of the world food economy, the aquaculture sector is usually poorly planned and neglected by all levels of the government (Costa-Pierce, 2010). In Africa, despite 40 years of research, development, and money spent, aquaculture is still struggling to realize its high biophysical potential (Brummett et al., 2008). Nigeria has huge potentials for aquaculture business and there is an increase in the involvement of Nigerians in the sector. Notwithstanding the contributions of Nigerians 
in the sector, evident from an increase in aquaculture farmers from 5 percent to 20 percent between 2001 and 2011, Nigeria is still not on the list of the largest producers of fish (Richard and Ogba, 2016).

Nigeria is rich in water resources, with a lot of water bodies that can support aquaculture, especially the Niger Delta region which has many river networks which can provide suitable sites for aquaculture development (Aguilar and Nath, 1998; Richard and Ogba, 2016). Fish farming being a profit yielding business has provided direct and indirect benefits to the population which is being realized in terms of generating thousands of employment opportunities with relatively low environmental impacts (Michael, 2014) and enhanced socio-economic status of farmers (Oluwasola and Ajayi, 2012). One major productive and profit-oriented sector in Nigeria after oil is aquaculture enterprise, which in return contributed immensely to the Gross Domestic Product of 4.4 percent (Thompson and Mafimisebi, 2014).

Cage culture can be established in any suitable body of water, including lakes, ponds, mining pits, streams or rivers with good water quality (Masser, 1988). This flexibility makes it possible to exploit underutilized water resources to produce fish. Relative to the cost of pond construction and its associated infrastructure, cage culture on an existing water body can be less expensive (Masser, 1988; Piccolotti and Lovatelli, 2013). Establishing a Tilapia cage culture must follow a careful evaluation based on a feasibility study that considers various aspects of the proposed location. To be compatible with an environment, the specie must find the right conditions which meets its physiological requirements for survival.

Site suitability in a Geographic Information Systems (GIS) context is a process used to determine the appropriateness of a given area for a particular use (FAO, 1976). The basic premise of GIS suitability analysis is that each aspect of the landscape has intrinsic characteristics that are to some degree suitable or unsuitable for the activities being planned. Model inputs include a variety of physical, cultural and economic factors. The results are often displayed on a map that is used to highlight areas of high to low suitability. A GIS suitability model typically answers the scientific question, "where is the best location?"(Njoku and Alagbe,2015).

The main problem in selecting suitable sites for Tila- pia farming is the lack of baseline information about physicochemical and topographic conditions and existing land-use patterns. Site selection processes that affect suitability for the intended purpose is essential for Tilapia farming development (Hossain et al., 2007). Inappropriate land use for Tilapia farming without considering necessary factors can lead to devastating yields, misuse of natural resources, degradation of the environment and other social conflicts (Giap et al., 2005). To alleviate these potential problems, suitability evaluation can be used to predict site performance on the basis of its attributes by using a variety of analytical models (Hossain et al., 2007).

Site selection or site suitability evaluation is a prerequisite for the success and sustainability of any aquaculture development (Hadipour et al., 2014, Hossain and Das, 2010). It is an innovative technology in industrial fish production that helps reduce the resource constraints and socio-environmental impediment to commercial aquaculture (Klinger and Naylor, 2012). The right selection of a site has influence not only in the potential of the activity but also in the social, environmental and economic sustainability of the agro-business. Notably, not all ponds or water bodies are suitable for cage culture of fish and many failures in cage production have occurred because of poor site selection. Technological advancement has been introduced to effectively establish and manage aquaculture especially with the recent introduction of GIS and remote sensing technologies (James and Jose, 2007).

GIS is increasingly becoming an integral component of natural resource management worldwide (Nath et al., 2000; Ross et al., 2010). The deployment of geospatial techniques for spatial decision support in aquaculture, however, continues to be low, although there are indications that the tools are receiving attention (Nath et al., 2000) as reported in some literatures. GIS multi-criteria evaluation (MCE) methods have been applied for aquaculture studies with considerations to human resources, physical characteristics, economics, markets and sociocultural resources (Salam et al., 2002). FAO used a MCA model that related soil type, precipitation, evapotranspiration, seepage, slope, agricultural activities, animal husbandry activities, human population, roads, market size and temperature to establish fish production parameters (Aguilar and Nath, 1998). Also, Hadipour et al. (2014) presented a GIS MCE model using the analytical hierarchy process 
(AHP) method to identify the most suitable sites for shrimp farming development in Hormozgan, Iran.

This study thus aimed to execute a GIS site suitability assessment for Tilapia cage culture in Cross River State, based on specific criteria. The suitability criteria were firstly determined to guide the selection of the most suitable sites for Tilapia cage culture using a multi-criteria technique. The outcomes of the study would be of interest to government agencies responsible for promoting and monitoring aquaculture development and to individual investors wishing to identify suitable sites for Tilapia cage culture. It also provides baseline methodology to assist planners and future researchers for site selection in aquaculture development.

\section{Materials and Methods}

\section{Location}

The location of this study is Cross River State, Nigeria. It is a coastal state in the south-eastern region of Nigeria, named after the Cross River, which meanders through the state. Located in the Niger Delta, Cross River State occupies 20,156 square kilometers. It shares boundaries with Benue State to the north, Ebonyi and Abia States to the west, to the east by Cameroon Republic and to the south by Akwa-Ibom State and the Atlantic Ocean. The capital of the state is Calabar and there are 18 Local Government Areas (LGAs) in the state. In the 2006 population and housing census, according to the National Population Commission (NPC), Cross River State was made up of 1,471,967 males and 1,421,021 females. Figure 1 shows the administrative boundaries of the state as well as the rivers that meander across the state from Yala and Obanliku in the north to the creeks that empty into the Atlantic Ocean in the southern portion of the state. The Cross River, a fresh alluvial river, is a major river in Nigeria and is a major consideration in this study. Also, is the Calabar River which is a tributary of the Cross River and the Great Kwa River which forms a part of the Cross River estuarine complex that discharges into the Atlantic Ocean.

\section{Data types and sources}

Data were sourced essentially from secondary sources as shown in Table 1. State and LGA boundaries as well as locations of communities were collected from the Office of the Surveyor General of the State. The Digital Elevation Model (DEM) of the area was acquired from United States Geological Survey (USGS) elevation data which was processed to derive the elevation and slope of the area. Further, Landsat 8 satellite imagery of December 2017 was acquired from the Land Look platform. The imagery was classified to derive the varying land uses within the area. Also, the road data was acquired from onscreen digitizing on the Google Earth platform. For the population data, the NPC census data of the 2006 was adopted. Also, average rainfall and temperature data were collected from Climatedata.org and compared with the data from Nigerian Meteorological Agency (NIMET) Seasonal Rainfall Prediction - SRP (2017).

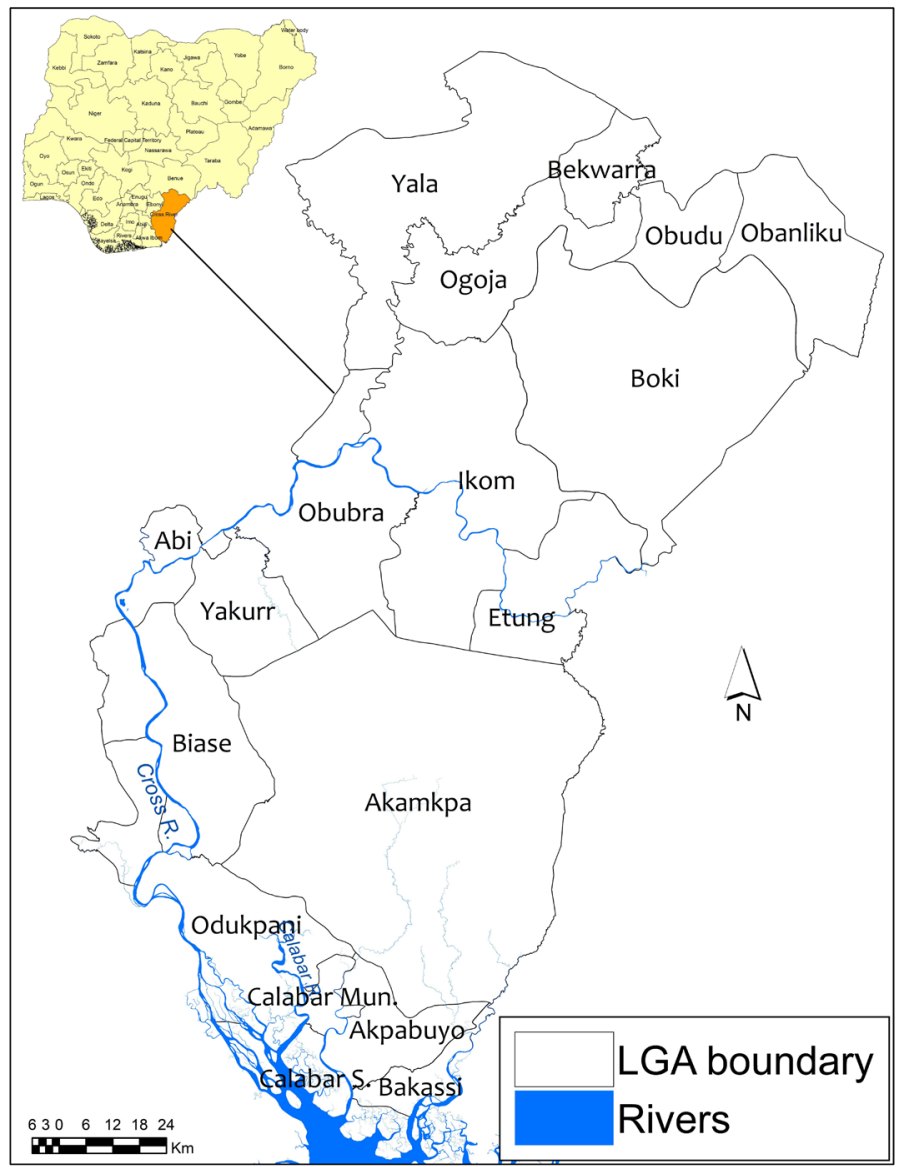

Figure 1: Map of Cross River State.

\section{Cartographic model}

Cartographic modeling is a process of organizing basic analytical operations in a logical sequence such that the output from one is the input to the next. In this study, the cartographic model in Figure 2 shows the step-by-step procedures of combining declared data (layers) to identify the most suitable locations for Tilapia cage culture on all the rivers in Cross River State. It depicts the datasets used, processes applied and results obtained. The process, as adapted from Njoku and Alagbe (2015), begins with collecting needed data for the assessment through from primary or secondary sources, expert judgment and literatures. 
Table 1: Summary of data sources, criteria and threshold for siting tilapia fish cage culture.

\begin{tabular}{|c|c|c|c|c|c|c|}
\hline $\mathrm{S} / \mathbf{n}$ & Criteria & Unit & $\begin{array}{l}\text { Most Suita- } \\
\text { ble (I) }\end{array}$ & $\begin{array}{l}\text { Moderately } \\
\text { Suitable (II) }\end{array}$ & $\begin{array}{l}\text { Not Suitable } \\
\text { (III) }\end{array}$ & Data Sources \\
\hline A & Location Attributes & & & & & \\
\hline 1 & Adjacent land area & Sqm & $>150,000$ & 150,000 & $<150,000$ & Landsat imagery \\
\hline 2 & Water surface area & $\mathrm{Sqm}$ & $>6070$ & 6070 & $<6070$ & Landsat imagery \\
\hline $2 \mathrm{a}$ & Water surface width & Meter & $>300$ & & $<200$ & Landsat imagery \\
\hline $\mathrm{B}$ & Weather variables & & & & & \\
\hline 3 & Average temperature & ${ }^{\circ} \mathrm{C}$ & $21-35$ & & & NIMET-SRP, Climatedata.org \\
\hline 4 & $\begin{array}{l}\text { Average precipitation } \\
\text { (Rainfall) }\end{array}$ & Millimeter & $>=1500$ & & $<1500$ & NIMET-SRP \\
\hline $\mathrm{C}$ & Topography & & & & & \\
\hline 5 & Slope & $\%$ & 0 to 5 & 5 to 15 & $>15$ & $\begin{array}{l}\text { USGS elevation data processed } \\
\text { with TCX Converter }\end{array}$ \\
\hline 6 & Elevation & Meter & $<20$ & & $>20$ & $\begin{array}{l}\text { USGS elevation data processed } \\
\text { with TCX Converter }\end{array}$ \\
\hline $\mathrm{D}$ & Anthropogenic activities & & & & & \\
\hline 7 & $\begin{array}{l}\text { Distance to population } \\
\text { density }\end{array}$ & $\begin{array}{l}\text { Persons/ } \\
\text { Sqkm }\end{array}$ & $<1000$ & 1000 to 1500 & $>1500$ & National Population Commission \\
\hline 8 & Distance to built-up areas & Kilometer & $<1000$ & & $>1000$ & Spatial measurements \\
\hline 9 & Distance to access road & Meter & $<500$ & 500 to 1000 & $>1000$ & Spatial measurements \\
\hline 10 & Landuse type & & $\begin{array}{l}\text { Grassland, } \\
\text { Light forest }\end{array}$ & $\begin{array}{l}\text { Paddy culti- } \\
\text { vation }\end{array}$ & $\begin{array}{l}\text { Forest, Swamp, } \\
\text { Plantation, Sand } \\
\text { Sedimentation. }\end{array}$ & $\begin{array}{l}\text { Landsat imagery/ field observa- } \\
\text { tion }\end{array}$ \\
\hline
\end{tabular}

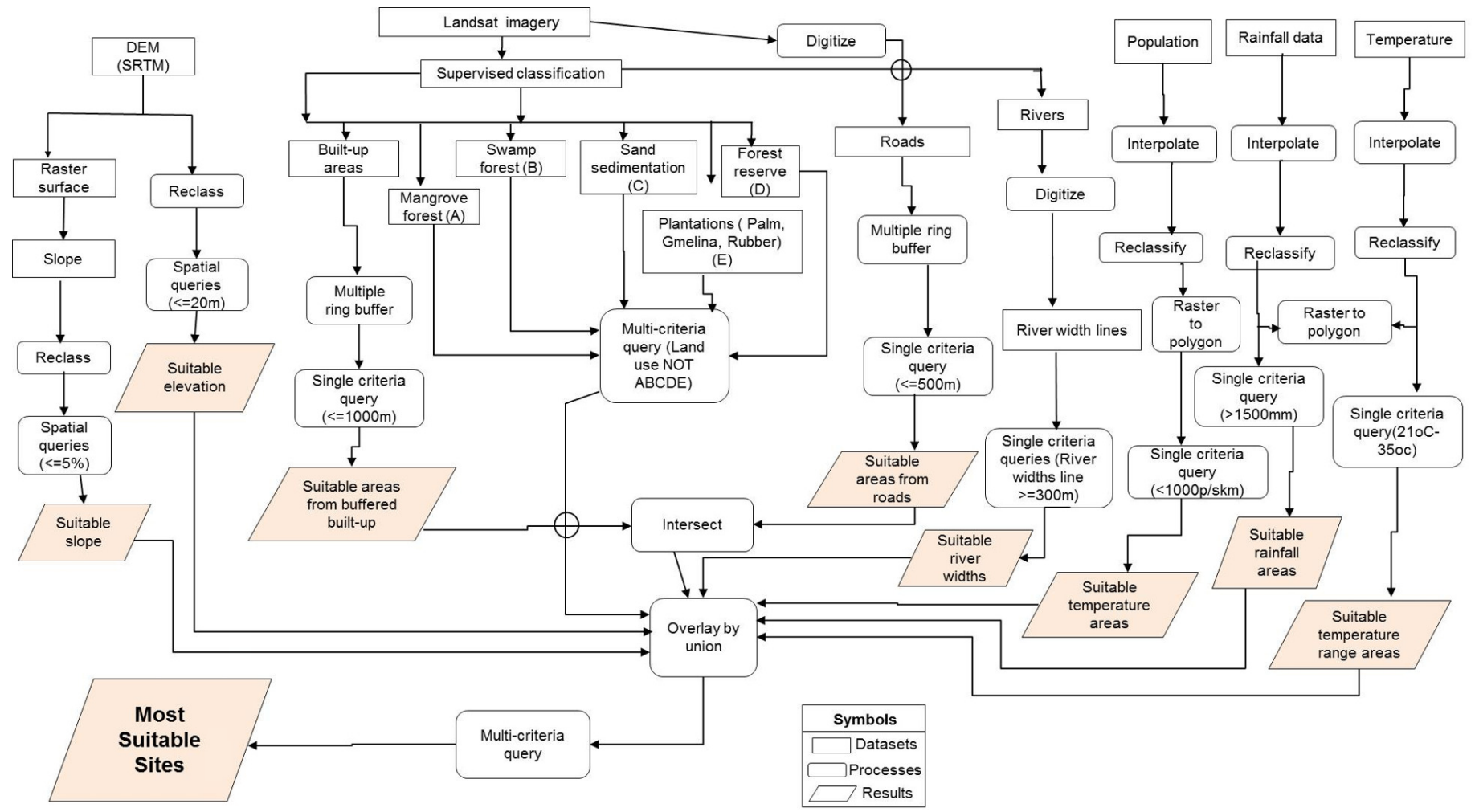

Figure 2: Cartographic model.

Site selection criteria

Different sites may be adapted to cage culture. Potential sites include lakes, reservoirs, ponds, quarries, rivers and streams. There was no random earmarking June 2022 | Volume 38 | Issue 2 | Page 459 of sites before commencement of the process. Instead, the process availed the most suitable sites based on a series of single and multi-criteria assessments. The assessment was not particular to any of the rivers such 
as the Cross River, Calabar River and the Great Kwa River.

The most important factors influencing site suitability for Tilapia cage culture provided the basis for the assessment. Practical selection criteria and ranges of data were established for site evaluation. Threshold values relating to different levels of suitability for each criterion were defined mainly through adaptations of criteria used in previous related studies. Criteria adaptations were compiled from earlier studies of Masser (1997), Ragbirsingh and De Souza (2005), Hossain et al. (2007), Kasozi et al. (2016) and Masuda et al. (2004). Other criteria considerations were adapted from Ssegane et al. (2012) who considered water temperature, terrain slope, potential farm gate sales, access to local and regional markets as factors and so on. Also from Hossain et al. (2007), who adopted the valuation of water and soil quality, topography, infrastructure and socio-economic factors; as well as Assefa and Abebe (2018), who considered biophysical and socioeconomic indicators. Criteria were also adapted from Ogunlade (2020) whose study examined the interplay between land cover/land use and slope in site suitability and Hunter (2009) who adopted cage site suitability, particulate dispersion, sensitivity biodiversity indicators and visual landscape capacity. Table 1 is thus a summary of criteria and threshold adopted for selection of Tilapia fish cage culture sites in Cross River State, as well as data sources for each criterion.

\section{Data analyses techniques}

The criteria considered were analyzed individually and further subjected to a MCE process. The elevation, slope, land use, population density, rainfall volume, temperature, distance from built-up areas and roads, as well as river width criteria were analyzed using the ArcMap software.

To derive the DEM, the elevation data was interpolated with the Inverse Distance Weighting (IDW) technique and further reclassed to 15 classes to accommodate the multiple elevation system in Cross River State. The elevation data was measured in meters. Similarly, the slope information was derived from the DEM using the slope tool. The slope derived was re-classed into 10 classes and measured in percentage. For both the elevation and slope classification process, the natural breaks classification method was adopted.

Based on the Landsat imageries acquired, the super- vised classification process availed the various land use classes in the State. The reflectance signature of the land use characteristics aided in the signature training for the classification. Ten different land use classes were determined. Specifically, farmlands, shrubs, bare lands and light forests which are more suitable adjourning land areas to river sites for Tilapia cage culture were grouped as one class for easy MCE.

Further, the population data was interpolated using same IDW to derive a population density map. The surface raster derived was reclassified to provide distinct classes that allowed for a vector suitability assessment. The raster was reclassified into 9 classes and further polygonised. Similarly, the average rainfall and temperature data values were also interpolated to make for representative coverage of the State. Both datasets were also reclassified into 9 classes.

To accommodate the least size of 6070 square meters $(80 \mathrm{~m}$ by $70 \mathrm{~m})$ stipulated in Table 1 as suitable size for the Tilapia cage culture activity, the width of the river must not be less than $300 \mathrm{~m}$. To achieve this, lines were digitized across the river portions with lines that measured less than $300 \mathrm{~m}$ were excluded. Also, multiple ring buffers were created around built-up areas (extracted from the land use map) and roads data to include areas less than $1000 \mathrm{~m}$ and $500 \mathrm{~m}$ respectively.

\section{Single and multi-criteria query}

Single criteria queries were carried out to determine the most suitable sites for each of the criteria. The queries were executed based on the criteria and threshold for siting a Tilapia aquaculture farm given in Table 1. The analyses were done using the Structured Query Languages (SQLs) shown on the cartographic model (Figure 2).

The final process in determining the most suitable sites for Tilapia cage culture sites was the multi-criteria spatial queries executed on an overlay-by-union of the all the datasets extracted from the single criteria queries. Prior to the final overlay, the overlay by intersection process of the rivers and the suitable sites from built-up areas and roads provided the suitable sites on the rivers from roads and built-up activities. A multi-criteria query on all the overlaid datasets using the SQLs (see process in Figure 2) returned the most suitable sites for Tilapia cage culture in the state. 


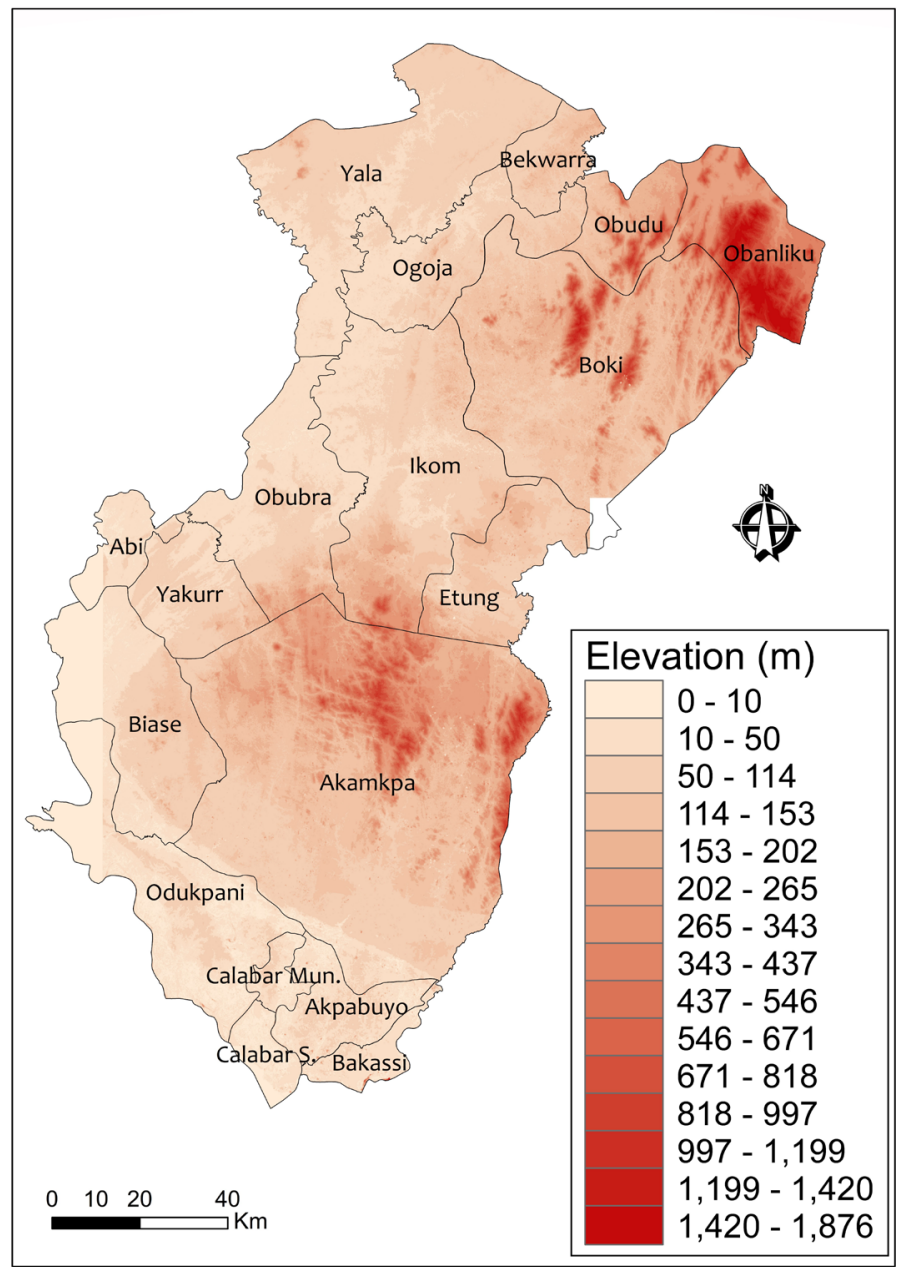

Figure 3: Elevation of Cross River State.

\section{Elevation criterion}

The elevation map (Figure 3) shows that the highest elevations in the State are in Obanliku LGA with elevations as high as $1876 \mathrm{~m}$ above mean seal level (AMSL). Obudu and Boki also showed high elevations as well as Akamkpa. The southerly areas close to the estuarine and areas at the edge of the Cross River have low elevations less than $10 \mathrm{~m}$ AMSL. Elevations adopted as suitable $(<=20 \mathrm{~m})$ are visible along the course of the Cross River.

\section{Slope criterion}

As shown in Figure 4, Obanliku, Akamkpa, Boki and Obudu LGAs have the highest slope percentages with values ranging from 35 percent to 87 percent. The areas with lesser slope percentages such as Calabar South, Odukpani, Biase, Abi, Yakurr, Ikom, etc. have values less than 35 percent and some afore-mentioned areas as low as less than 5 percent. In this selection process, the slopes with percentages less than or equal to 5 were considered. These areas were identified mostly at the western corridor of the State as well as in Ikom, Etung and Akamkpa LGAs.

\section{Landuse criterion}

Figure 5 shows that the forest reserve covers as much as a third of the area. Other land uses identified include plantations of palm, gmelina and rubber. The mangrove and swamp forests are more prevalent in the southern axis. For most other parts of the state, the land cover is a mix of farmlands, light forests, shrubs and bare lands. Because of the need to have a usable adjacent land by the suitable portion of water, it became necessary to assess these land use characteristics. As specified in Table 1, areas such as reserved forest, swamps, mangroves and plantations are not suitable in the selection process. Also, spots identified to be portions of sand sediments on the water body were also avoided. Built-up areas were also considered and portions of the rivers at a range of 1000 $\mathrm{m}$ from human built-up activities were considered suitable.

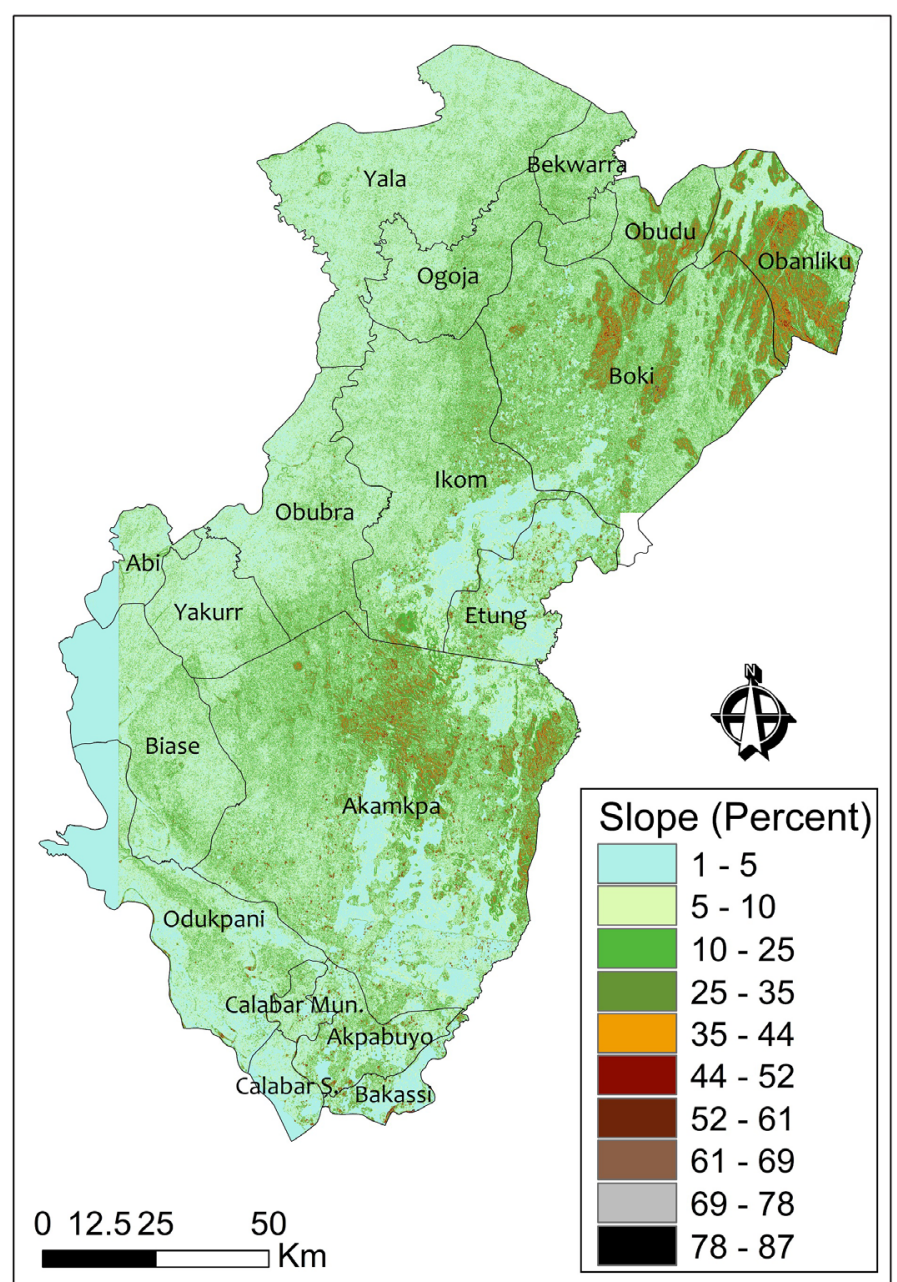

Figure 4: Slope of Cross River State.

\section{Population density criterion}

As shown in Figure 6, the locations with high population densities, more than the stipulated standard are Calabar Municipality and Calabar South LGAs. These areas have more than 958 persons per square 
kilometer. The map (Figure 6) shows the spatial distribution of population in the state. Obviously, there is more density of people in the capital city, a teeming population which is not suitable to be in proximity of a Tilapia aquaculture. This density however lightens out farther away.

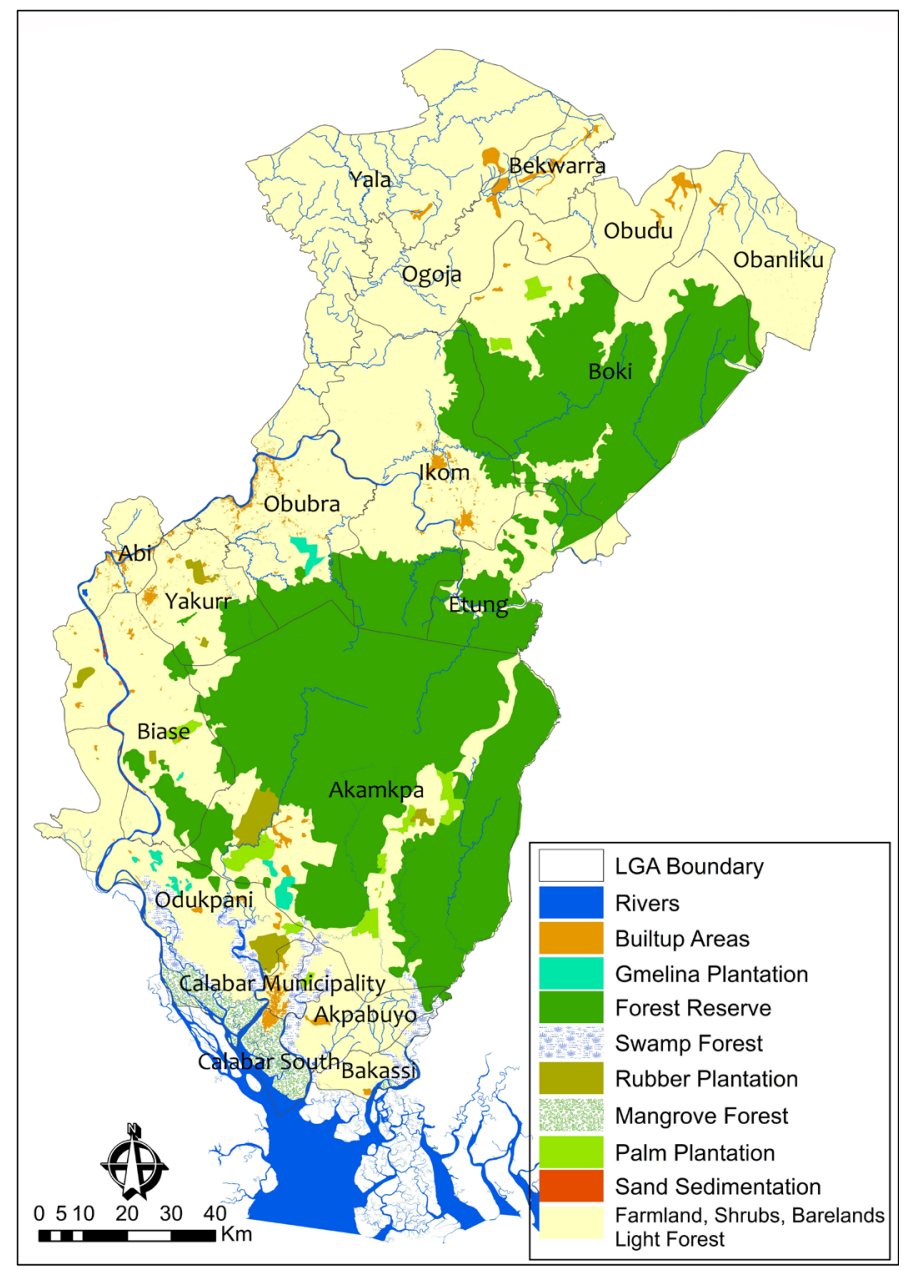

Figure 5: Land use land cover of Cross River State (2017).

\section{Rainfall volume and temperature criteria}

Figure 7 shows the output of the rainfall coverage analysis. Rainfall volume is high in the area with every LGA getting a fair share of the precipitation. However, the lowest rainfall volume was recorded in Boki LGA with between 1180 to $1514 \mathrm{~mm}$ per year. This is the only area revealed not suitable for Tilapia aquaculture in the State. The other areas have rainfall volumes, higher than the prescribed $1500 \mathrm{~mm}$, enough to replenish the water bodies, with the southern axis (Calabar South, Calabar Municipality, Akpabuyo and Bakassi) recording the highest precipitation in the State.

Also, the temperature assessment shows that every location in the State is within the stipulated temperature range of $21^{\circ} \mathrm{C}$ to $32^{\circ} \mathrm{C}$. The highest mean tem

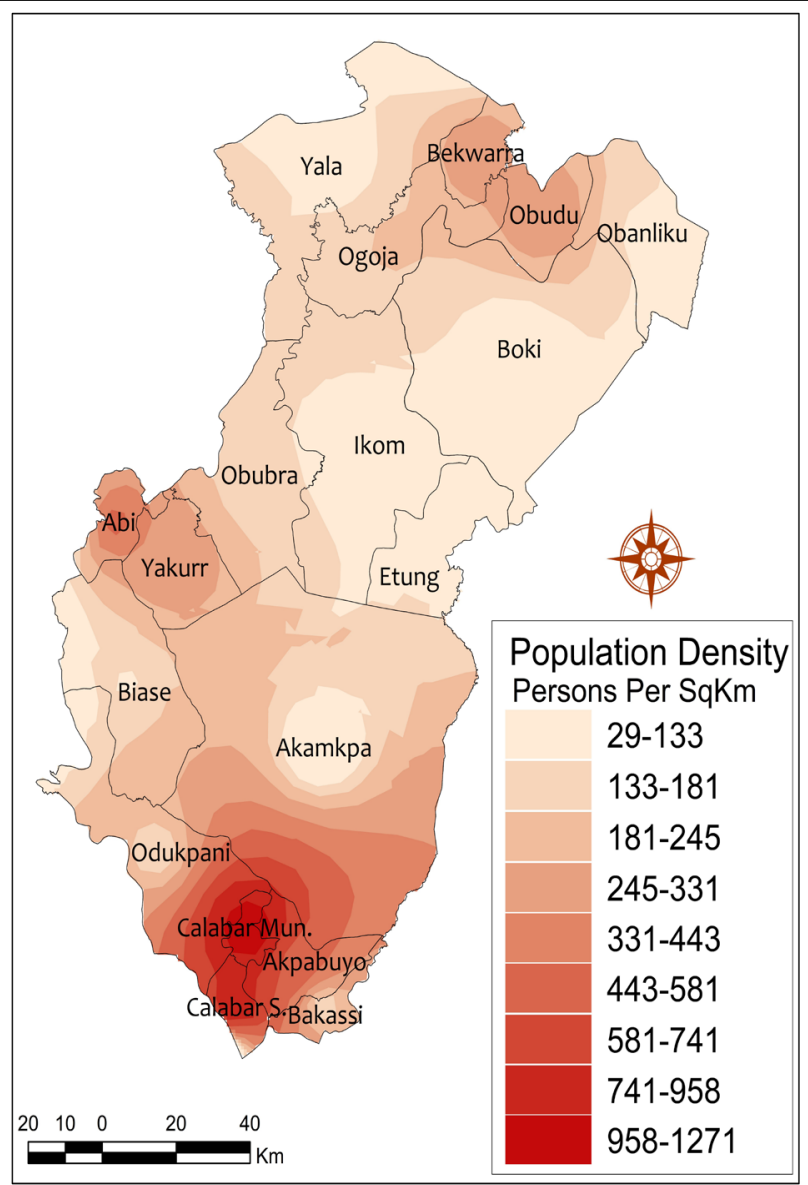

Figure 6: Population density of Cross River State (2006).

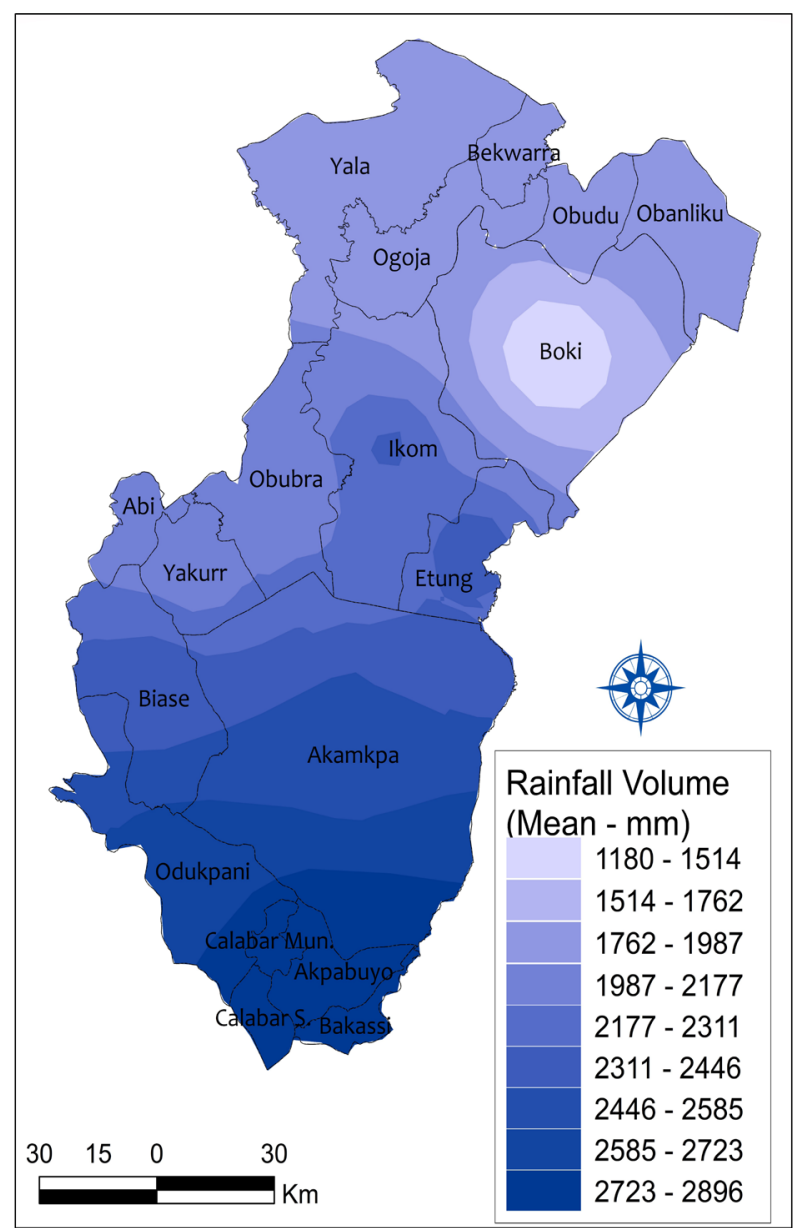

Figure 7: Average rainfall volume of Cross River State (2017). 


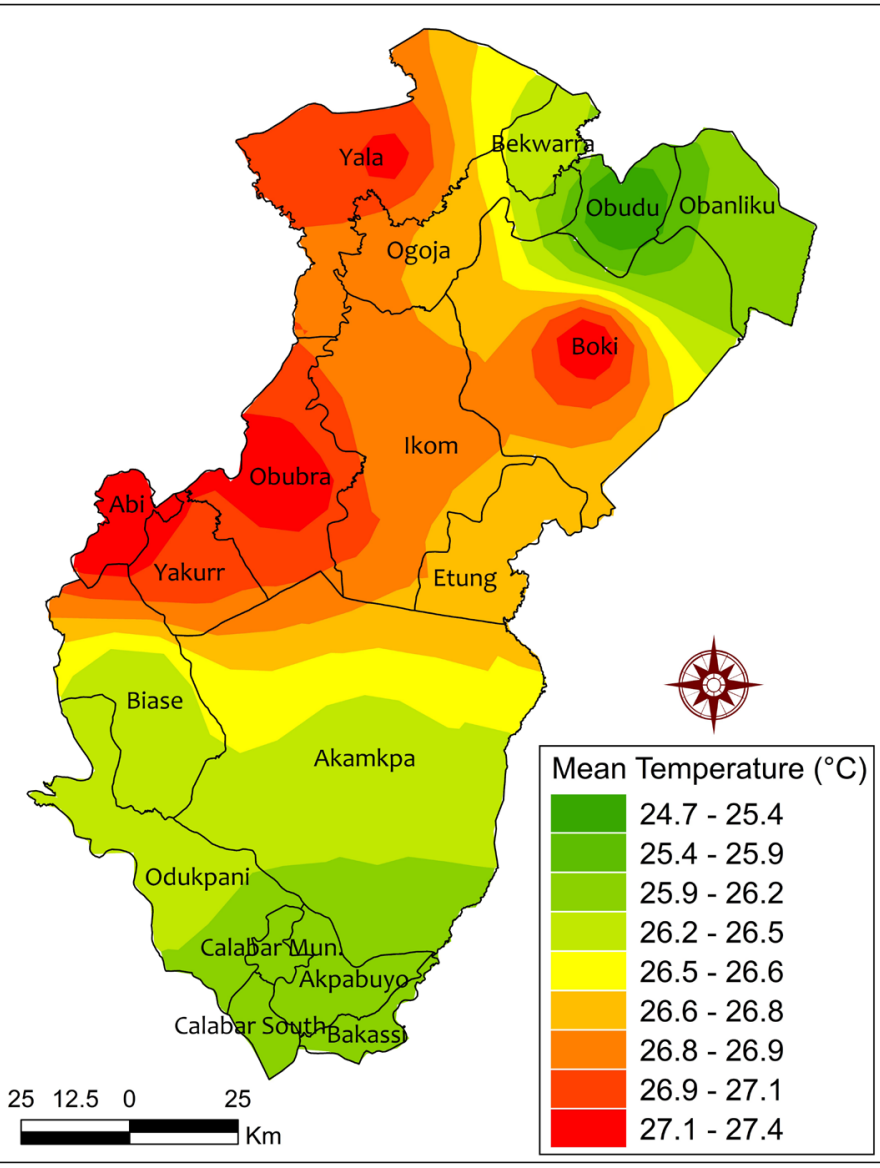

Figure 8: Average temperature of Cross River State (2017).

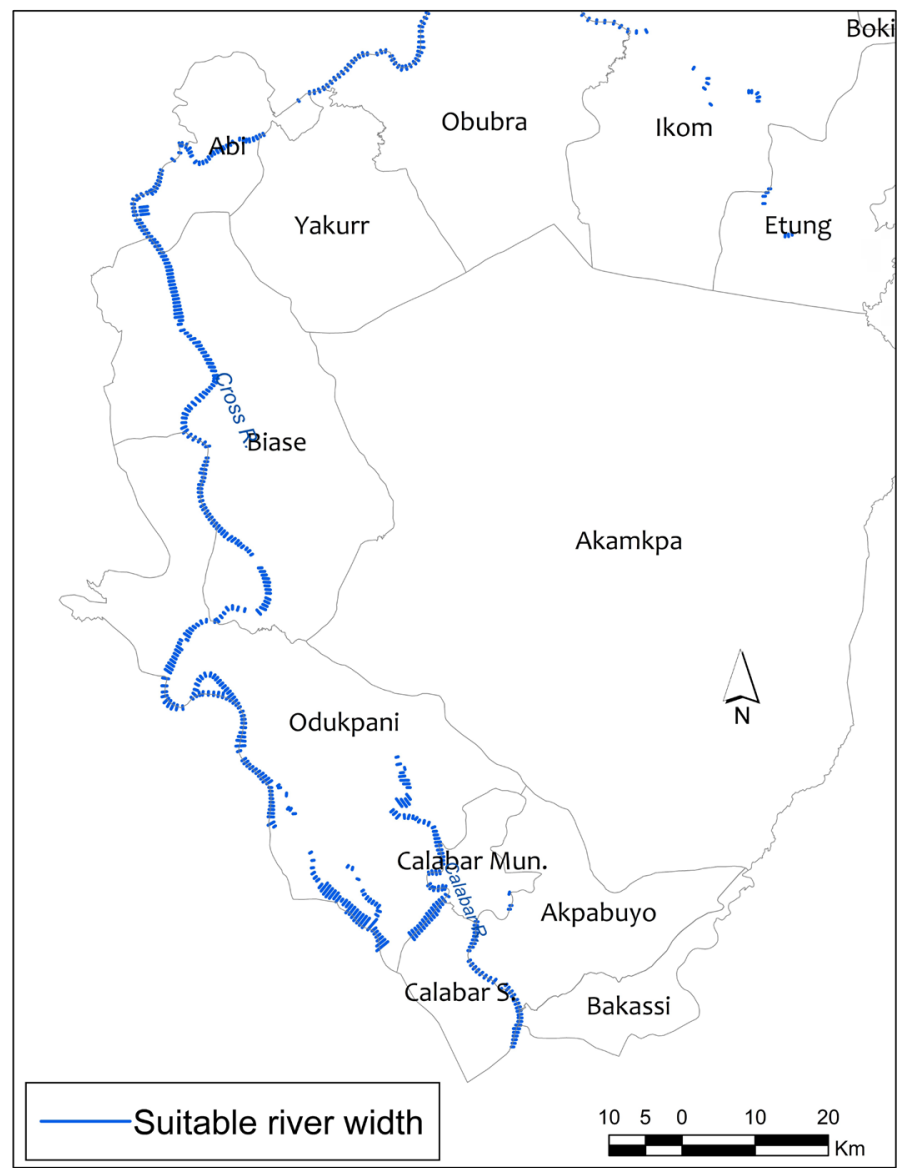

Figure 9: Suitable River width lines. peratures were visible in the central parts of the state as well as the north western corner. Parts of Obudu and Obanliku LGAs, as seen on Figure 8 have the lowest mean temperature value of $24.7^{\circ} \mathrm{C}$ to $25.4^{\circ} \mathrm{C}$. It is proven that temperature affects fish metabolism, enhancing or retarding their growth. Although it is unlikely to kill them, except at extreme temperature regimes, which is rarely the case in Cross River State. Tilapia production is sometimes constrained in its current areas of production by temperature. Some species such as Tilapias and striped catfish are more likely to be affected by weather conditions as demonstrated by the huge loss of Tilapia during particularly cold periods of 2008 in China (Cai and Liufu 2008). The normal temperature in the natural habitat of $\mathrm{Ti}^{-}$ lapia ranges between 21 to $35^{\circ} \mathrm{C}$ and could be taken as optimum temperature range for cultured fish farming. An annual rainfall of at least $1500 \mathrm{~mm}$ is a precondition for any area to be suitable for fish farming. This is because rainfall is the ultimate source of water and rejuvenates the cycle, especially for the rivers that are somewhat inland (Masuda et al., 2004).

\section{River width assessment}

Figure 9 shows portions on the rivers with widths more than $300 \mathrm{~m}$. These measured lines run across the rivers and were drawn to determine the rivers with widths suitable for the Tilapia farming activity. This width would allow for an offset of at least $20 \mathrm{~m}$ from the adjourning land and at least $200 \mathrm{~m}$ after the demarcation of the pond to the other end of the river. This is to give room for other users of the river to carry out their activities such as transportation and fishing.

\section{Suitable distance from built-up areas and roads}

Figure 10 depicts the locations on the water bodies that are at suitable distances from built-up areas. These locations are less than $1000 \mathrm{~m}$ from built-up areas. In as much as excessive human activities are unsuitable, where human activities are too far from the fish farms, it becomes more tedious to cater for the fish, because of the need for man-power and equipment. More so, because of the necessity of an access road to the farm, a buffer of $500 \mathrm{~m}$ away from the existing roads was done. Figure 11 shows the suitable river sites from roads. The proximity to existing roads would not only save cost for constructing a new access path to the water, but also means the portion of land and water in the vicinity of the road has been explored and is most likely usable for anthropogenic activities. 


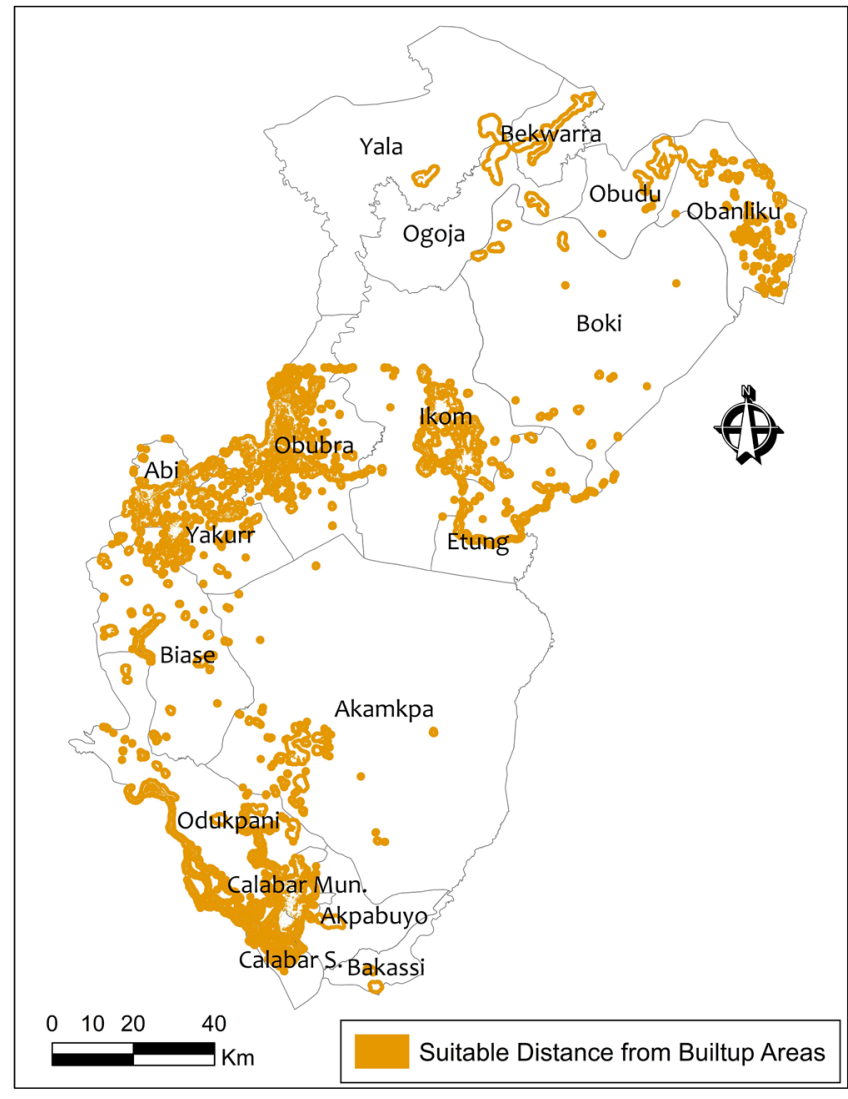

Figure 10: Suitable River sites from built-up areas.

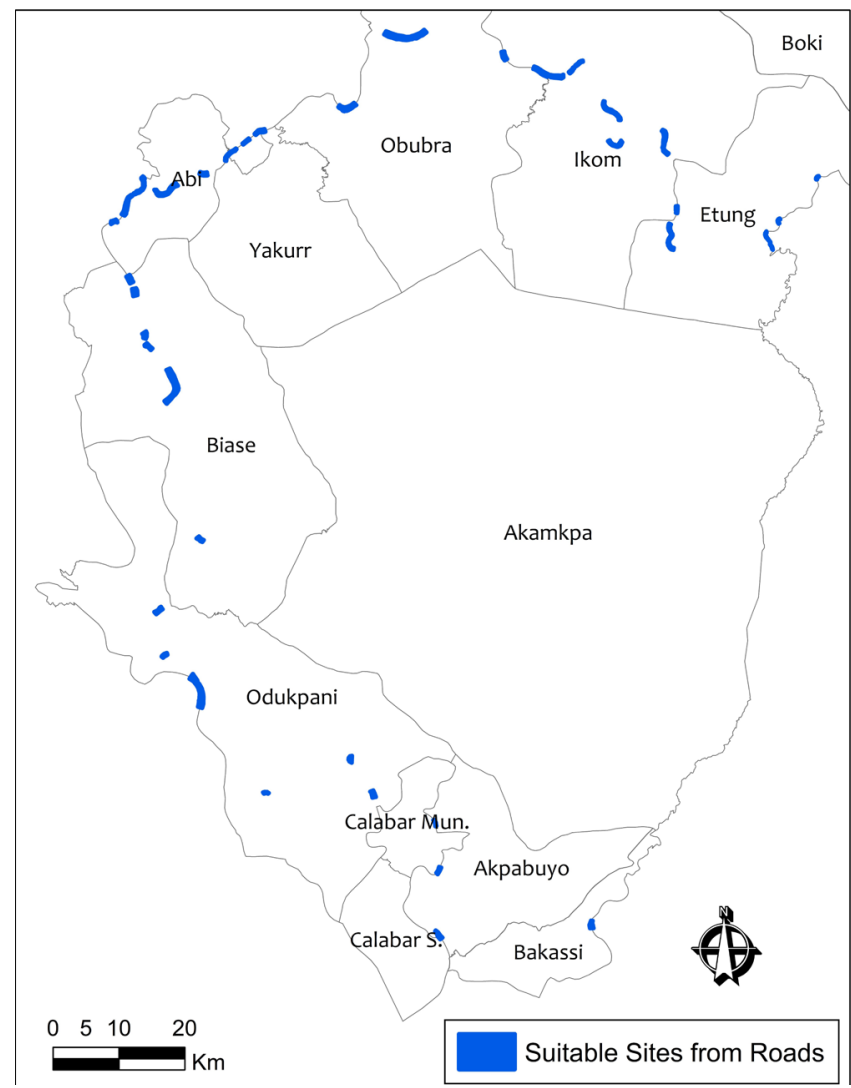

Figure 11: Suitable River sites from roads.

\section{Spatial query outputs}

The analysis from the single criteria analyses showed suitable sites based on each factor considered. The suitable elevation (less than $20 \mathrm{~m}$ ) and slope areas June 2022 | Volume 38 | Issue 2 | Page 464 (less than 5 percent) such as areas adjourning the water bodies in Odukpani, Abi, Biase LGAs, and so on were extracted based on the analyses in Figure 3 and Figure 4 respectively. The land use areas most suitable (farmlands, shrubs, light forests and bare lands) are also depicted in Figure 5. As well, the suitable areas based on population density (less than 1000 persons per sq $\mathrm{km}$ ) were extracted from the population density map as shown in Figure 6. Also, the areas with the most suitable precipitation volume (more than 1500 $\mathrm{mm}$ ) such as the southern parts of the State were extracted from the average rainfall volume map in Figure 7, while the areas within the suitable temperature ambient $\left(21^{0} \mathrm{C}\right.$ to $\left.35^{\circ} \mathrm{C}\right)$ were delineated from the average temperature map in Figure 8. Further, Figures 10 and 11 show the suitable sites from built-up areas and roads. The maps show the portions of the rivers that are suitable based on the proximity to roads and anthropogenic activities.

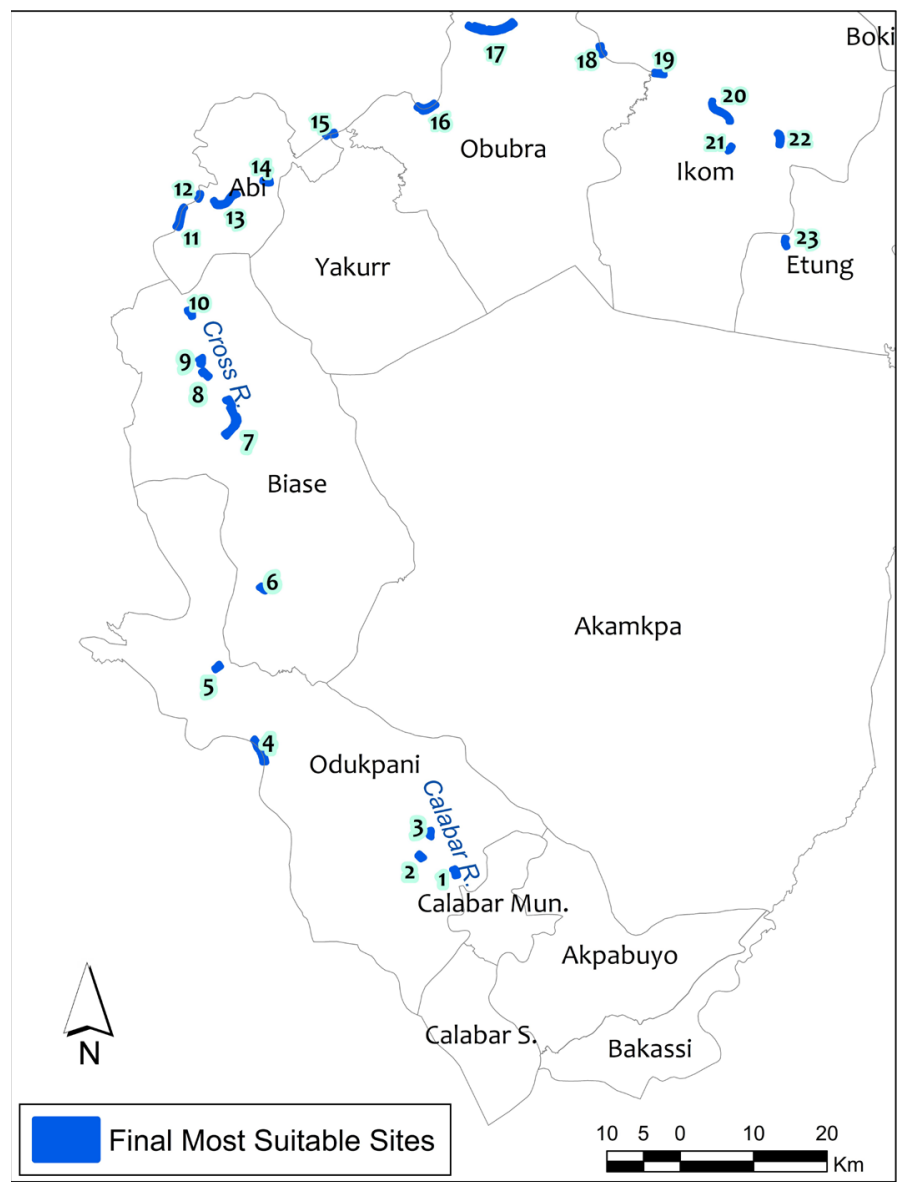

Figure 12: Most suitable sites for Tilapia cage culture in Cross River State.

A total of 23 sites were derived (Figure 12). The analysis as shown on Table 2 reveals that the highest number of sites most suitable for cage culture are in Biase and Odukpani (5 sites each). Abi and Ikom had 4 sites each. Whereas most other LGAs in the 
Table 2: Attribute data of the most suitable sites.

\begin{tabular}{|c|c|c|c|c|c|c|}
\hline $\begin{array}{l}\text { Site } \\
\text { Id }\end{array}$ & LGA & Longitude & Latitude & Nearest Community (ies) & Rivers & $\begin{array}{l}\text { Area Coverage on water } \\
\text { (Hectare) }\end{array}$ \\
\hline 1 & Odukpani & 81821.371 & 5322.135 & Adiabo, Ukpakata, & Calabar River & 44 \\
\hline 2 & Odukpani & 81523.55 & 5415.44 & Adiabo, Okurikang & Calabar River & 33 \\
\hline 3 & Odukpani & 8163.199 & 5610.893 & Adiabo, Ikot Ukpo & Calabar River & 38 \\
\hline 4 & Odukpani & 843.428 & 51211.194 & $\begin{array}{l}\text { Ikot Essien Ekpe, Ikot Etam Oku, } \\
\text { Mbia Ikoeto }\end{array}$ & Cross River & 152 \\
\hline 5 & Odukpani & 8038.215 & 51815.071 & Obiono Beach, Obodo, Ikot Ndaw & Cross River & 34 \\
\hline 6 & Biase & 847.385 & 52421.563 & Utum, Idun, Itu & Cross River & 36 \\
\hline 7 & Biase & 8129.948 & 53541.908 & Okurike, Ibinabam, & Cross River & 245 \\
\hline 8 & Biase & 75949.152 & 54012.263 & Ikun Beach & Cross River & 43 \\
\hline 9 & Biase & 75937.02 & 5419.104 & Itu Agwagune & Cross River & 48 \\
\hline 10 & Biase & 75949.337 & 54443.543 & Abariba & Cross River & 44 \\
\hline 11 & Abi & 75755.305 & 5517.689 & Ebijakara & Cross River & 111 \\
\hline 12 & Abi & 8115.815 & 55240.234 & Afafanyi & Cross River & 143 \\
\hline 13 & Abi & 75925.624 & 55316.222 & Afafanyi & Cross River & 22 \\
\hline 14 & Abi & 8412.032 & 55415.306 & & Cross River & 45 \\
\hline 15 & Yakurr & 894.819 & 55749.283 & Igbo Beach, Ikpalagwa & Cross River & 53 \\
\hline 16 & Obubura & 81533.942 & 55945.384 & Ofodua, Adun Beach & Cross River & 124 \\
\hline 17 & Obubura & 81923.709 & 6543.241 & Obubura, Owakande & Cross River & 302 \\
\hline 18 & Obubura & 82849.76 & 649.096 & Onyen Nkun Apanbe & Cross River & 49 \\
\hline 19 & Ikom & 83314.43 & 62131.709 & Abaragba, Okosora & Cross River & 50 \\
\hline 20 & Ikom & 83741.027 & 55944.40 & Ekpokpa & Cross River & 103 \\
\hline 21 & Ikom & 83812.132 & 55640.37 & Akayuk Opuowe & Cross River & 25 \\
\hline 22 & Ikom & 84216.508 & 55730.155 & Egrude & Cross River & 63 \\
\hline 23 & Etung & 84226.38 & 54957.96 & Abijan, Agbotai & Cross River & 36 \\
\hline
\end{tabular}

state are without sizeable river widths and unsuitable based on a combination of other parameters, Yakurr and Etung has the least number of suitable sites.

Additionally, Table 2 provides attribute data of the most suitable sites. The 23 derived sites are polygon features, each covering extents greater than the given 6070 square meters on the surface of the water. The table depicts the spatial location of the suitable sites (coordinates), nearest communities to the site, the name of the river where the site is located and the area coverage of the sites.

Further measurements also revealed that out of the total area coverage of the water bodies considered in Cross River State which measures 409.87 square kilometers, only a total of 18.44 square kilometers is suitable for Tilapia cage culture. This represents 4.49 percent of the water bodies in the State.

\section{Results and Discussion}

This study was designed to execute a GIS site suitability assessment for Tilapia cage culture in Cross River State based on specific criteria. The findings from this study and similar extant literature buttresses the role of GIS and MCE for precision agriculture with regards site suitability for aquaculture in Nigeria and elsewhere. For example, Hossain et al. (2007) emphasized that site selection is a key factor to be considered in the setting up of any aquaculture operation. This study revealed 23 suitable sites for Tilapia cage culture in Cross River State considering criteria such as elevation, land-use, accessibility (roads), river width, population density, distance from anthropogenic activities and climatic variables.

Similar to this study, Ross et al. (2010) deduced freshwater cage locations for Tilapia cage culture in Michoacan, Mexico through spatial modelling tech- 
niques adopting topography, climate, hydrography, water quality and quantity, land use, infrastructure and socioeconomics criteria. Hossain and Das (2010) in a similar vein also determined the best locations and extents for aquaculture in Noakhali, Iran at different suitability scales using land suitability modelling through a GIS based MCE. The researchers adopted the water quality, soil characteristics and infrastructure facilities as criteria for the site suitability selection. A similar study in Africa by Berg et al. (2021) in Tanzania considered different factors such as water availability, water temperature, soil texture, terrain slope, availability of farm inputs, potential farm-gate sales and access to local markets in the site selection process.

While the criteria used in the current study is similar to Ross et al., (2010) as well as Hossain and Das (2010), the current study did not adopt some criteria such as water quality as adopted by Ross et al. (2010), soil characteristics used in Hossain and Das (2010) or closeness to market as adopted by Berg et al. (2021). This is so as this study focused mainly on remotely sensed data to provide baseline information on site suitability for Tilapia cage culture in Cross River State. This limitation and inexhaustibility of the criteria for a site suitability assessment was also identified by Berg et al. (2021).

Furthermore, despite the arguably suitability of some locations in Calabar South, Akpabuyo and Calabar Municipality to criteria such as river width and distance to road, these sites were not considered suitable for the final suitability result because they do not pass the other criteria test. Similar results were also noted in Ross et al. (2010) where some sites were suitable for some criteria and unsuitable for others, hence the exclusion of those sites from the final suitability result.

The derivation of 23 suitable sites for Tilapia cage culture in Cross River State buttresses Aguilar and Nath's (1998) assertion that there are sufficient resources and potentials for small-scale and commercial fish farming in Nigeria's Niger Delta region. These potentials, if utilized sustainably, would have significant positive impacts on food security in the region. More so, this study showed that only 4.49 percent of the water bodies in Cross River State can be considered for setting up a Tilapia cage culture. Similar studies have as well shown that limited portions of water bodies are suitable for Tilapia cage culture, such as 28 percent of the water bodies in Tanzania (Berg et al., 2021) and only 9 percent of the Kenyan part of Lake Victoria (Aura et al., 2021). Considering the large expanse of water in Cross River State, the deduction that only an expanse of 4.49 percent of the water bodies is suitable for Tilapia cage culture can provide some limitations to the expansion of aquaculture in the area. It also buttresses the need for suitability assessments to restrict farmers to the limited specific locations that are best for Tilapia cage culture; else they jeopardize the productivity and sustainability of their ventures.

\section{Conclusions and Recommendations}

This study concludes that setting up a Tilapia cage culture is feasible on specific portions of the water bodies in Cross River State as findings from this study have revealed suitable locations based on a combination of different criteria. Adopting innovative technologies such as the site suitability assessment can improve the productivity and sustainability of aquaculture and food production as a whole in Nigeria.

Determining the best site for aquaculture involves a combination of diverse parameters that have potentials of influencing its productivity. With several factors capable of combinely affecting the outcome of a suitability assessment, this study thus provides a baseline assessment aimed to provide some direction for the future development of Tilapia cage culture in Cross River State.

The results indicate that there is potential for aquaculture development in the State as 23 suitable sites were identified for Tilapia cage culture. The result from this study thus confines or restricts the scope for subsequent scientific queries to only 23 portions of the rivers in Cross River State. The findings herewith can support policy formulation, decision making and invariably, sustainable water management for aquaculture and other uses.

Based on the findings from the study, the following are recommended:

1. There is an urgent need to reshape agriculture in Africa. With emphasis on aquaculture, it is necessary for small and large-scale farmers to carry out research on site suitability before commencing their farming. This would reduce the risk of failure 
after setup due to unforeseen environmental and social vagaries.

2. GIS and remote sensing have shown to play an integral role in aquaculture development and management. To actualize this, the barriers of using geospatial tools and findings for real world decision making in Nigeria has to be overcome. Individuals and organizations that are stakeholders in the geospatial industry must spearhead and facilitate the migration of GIS tools from the academia to the field (real world) and foster collaborations that would address the issue.

3. The results of this study can be further improved through site-specific assessments that would consider other factors such as hydrographic conditions (e.g., depth, currents), water quality (e.g., dissolved oxygen, $\mathrm{pH}$, temperature), river bed soil conditions (e.g., water retention) and socio-economic factors (e.g., infrastructure, security concerns).

\section{Acknowledgements}

We are grateful to Challawa River Nigeria Limited for the financial and moral support provided to carry out this study.

\section{Novelty Statement}

The study revealed the power of the MCE, combining elevation, slope, land use, population density, rainfall volume and temperature, river width and distance from built-up area criteria in identifying suitable sites for Tilapia cage culture. The study is relevant as it shows the locations suitable for Tilapia cage culture in Cross River State. It is as well timely because there is paucity of knowledge with regards to where aquaculture farmers can best site their farms, specifically for those that plan to invest in Tilapia cage culture in the State. It would thus not only serve as a baseline for further studies, especially in the area and in Nigeria at large where fish outputs are needed, but would support decision making and policy formulation.

\section{Author's Contribution}

Chukwudi Gbadebo Njoku: Wrote the background, collected data, developed the method, carried out data analyses and reporting.

Inyang Etim-Inyang: Conceptualized the study and assisted with reviewing the work.
Prince-Charles Itu: Assisted with data collection, literature review, discussion of results and also reviewed the work.

Arinze Uzoezie: Assisted with data analyses.

All authors read and approved the final manuscript.

\section{Funding Information}

This work was funded by Challawa River Nigeria Limited; an organization focused on improving food production in Nigeria through precision and sustainable agriculture, under its Tilapia Cage Culture Project.

\section{Conflict of Interest}

The authors declare that they have no known competing financial interests or personal relationships that could have appeared to influence the work reported on the paper.

\section{References}

Aguilar, M.J. and Nath, S.S. 1998. A strategic reassessment of fish farming potential in Africa. CIFA Technical Paper 32, Food and Agriculture Organization of the United Nations, Rome, Italy.

Assefa, W.W. and Abebe, W.B. 2018. GIS modeling of potentially suitable sites for aquaculture development in the Lake Tana basin, Northwest Ethiopia. Agric. Food Secur., 7: 72 (2018). https://doi.org/10.1186/s40066-018-0222-0

Aura, C.M., Musa, S., Nyamweya, C.S., Ogari, Z., Njiru, J.M., Hamilton, S.E. and May, L. 2021. A GIS-based approach for delineating suitable areas for cage fish culture in a lake. Lakes Reservoirs: Sci. Policy Manage. Sustain. Use, 26 (2). https://doi.org/10.1111//re.12357

Berg, H., Mulokozi, D. and Udikas, L. 2021. GIS Assessment of the Suitability of Tilapia and Clarias Pond Farming in Tanzania. ISPRS Int. J. Geo-Inf., 10 (354): 1-29. https://doi. org/10.3390/ijgi10050354

Brummett, R.E., Lazard, J. and Moehl, J. 2008. African aquaculture: Realizing the potential. Food Policy, 33: 371-385. https://doi.org/10.1016/j. foodpol.2008.01.005

Cai, Y. and Liufu, Y. 2008. Risk analysis of cold disaster of Guangdong fishery (in Chinese). Ocean Fishery, (4): 7-9.

Costa-Pierce, B.A. 2010. Sustainable ecological aquaculture systems: The need for a new social 
contract for aquaculture development. Marine Technol. Soc. J., 44 (3) 88-112. https://doi. org/10.4031/MTSJ.44.3.3

FAO. 1976. A Framework for Land Evaluation. Food and Agriculture Organization of the United Nations, Rome. Retrieved March 2021 from http://www.fao.org/3/x5310e/x5310e00. htm

FAO. 2014. The State of World Fisheries and Aquaculture. Opportunities and challenges. Food and Agricultural Organization of the United Nations, 2014. Retrieved March, 2021 from http://www.fao.org/3/i3720e/i3720e.pdf

FAO. 2018. The State of World Fisheries and Aquaculture. Food and Agricultural Organization of the United Nations. Retrieved August 2019 from http://www.fao.org/documents/card/ en/c/I9540EN/

Giap, D.H., Yi, Y. and Yakupitiyage, A. 2005. GIS for land evaluation for shrimp farming in Haiphong of Vietnam. Ocean Coastal Manage., 48: 51-63. https://doi.org/10.1016/j.ocecoaman.2004.11.003

Green Economy and Trade. 2013. Fisheries and Aquaculture, 1-36. Retrieved February, 2021 from http://www.unep.org/greeneconomy/ Portal/88/documents/ger/3.0_Fisheries.pdf

Hadipour, A., Vafaie, F. and Hadipour, V. 2014. Land suitability evaluation for brackish water aquaculture development in coastal area of Hormozgan, Iran. Aquacult. Int., https://doi. org/10.1007/s10499-014-9818-y

Hossain, M.S., Chowdhury, S.R., Das, N.G. and Rahaman, M.M. 2007. Multi-criteria evaluation approach to GIS-based land-suitability classification for tilapia farming in Bangladesh. Aquacult. Int., 15(6): 425-443. https://doi. org/10.1007/s10499-007-9109-y

Hossain, M.S. and Das, N.G. 2010. GIS-based multi-criteria evaluation to land suitability modelling for giant prawn (Macrobrachium rosenbergii) farming in Companigonj Upazila of Noakhali, Bangladesh. Comput. Electron. Agric., 70: 172-186. https://doi.org/10.1016/j. compag.2009.10.003

Hunter, D-C. 2009. GIS-based decision support tool for optimisation of marine cage siting for aquaculture: A case study for the Western Isles, Scotland. Thesis submitted for the degree of doctor of philosophy. Institute of Aquaculture, University of Stirling. Retrieved Novem- ber, 2021 from https://core.ac.uk/download/ pdf/40007448.pdf

James, M.K. and Jose, A.M. 2007. Geographic Information Systems, Remote Sensing and Mapping for the Development and Management of Marine Aquaculture. FAO Fisheries Technical Paper 458, 11 - 100. Retrieved July, 2020 from http://www.fao.org/3/a0906e/a0906e00.htm

Kasozi, N., Opie, H., Iwe, G., Enima, C., Nkambo, M., Turyashemererwa, M., Naluwayiro, J. and Sadik, K. 2016. Site suitability assessment of selected bays along the Albert Nile for Cage Aquaculture in West Nile region of Uganda. Int. J. Fish. Aquacult., 8(9): 87-93. https://doi. org/10.5897/IJFA2016.0562

Klinger, D. and Naylor, R. 2012. Searching for Solutions in Aquaculture: Charting a Sustainable Course. Annu. Rev. Environ. Resour., 37: 247-76. https://doi.org/10.1146/annurev-environ-021111-161531

Masser, M. 1988. What is cage culture? Southern Regional Aquaculture Center, Publication No. 160. Retrieved July, 2019 from https://www. ncrac.org/content/what-cage-culture

Masuda, K., Chirwa, B.B. and Ntenjera, G. 2004. The Project on Aquaculture Research and Technical Development of Malawian Indigenous Species. National Aquaculture Centre, Domasi Department of Fisheries and Japan International Cooperation Agency.

Michael, S. 2014. Aquaculture - The Benefits of Aquaculture. Retrieved June 2019 from http:// fishery.about.com/od/BenefitsofAquaculture/a/AquacultureBenefits.html

Nath, Bolte, Ross and Manjarrez. 2000. Application of Geographic Information Systems (GIS) for Spatial Decision Support in Aquaculture. Aquacult. Eng., 23 (1999): 233-278. https:// doi.org/10.1016/S0144-8609(00)00051-0

Njoku, C.G. and Alagbe, A.O. 2015. Site suitability assessment of Petrol Filling Stations (PFSs) in Oyo Town, Oyo State, Nigeria: A Geographic Information Systems (GIS) Approach. IOSR J. Environ. Sci., Toxicol. Food Technol. (IOSR-JESTFT). 12 (3): 08-19.

Nigerian Meteorological Agency. 2017. Seasonal rainfall prediction (SRP). Retrieved April, 2018 from http://www.nimet.gov.ng/publication/2017-seasonal-rainfall-prediction-srp

Ogunlade, S. 2020. Site suitability mapping for fish farming: a geospatial approach. Presented 
at the 3rd World Environmental Conservation

Conference 2020 at Wesley University Ondo, Ondo State, Nigeria. Retrieved September 2021 from https://www.researchgate.net/publication $/ 343480691$

Oluwasola, O. and Ajayi, D. 2012. Socio-economic and policy issues determining sustainable fish farming in Nigeria. Afr. J. Agric. Econ. Rural Dev., 1(1): 035 - 041. https://doi.org/10.5897/ IJLP12.013

Ottinger, M., Clauss, K. and Kuenzer, C. 2016. Aquaculture: Relevance, distribution, impacts and spatial assessments. A review. Ocean Coastal Manage., 119: 244-266. https://doi. org/10.1016/j.ocecoaman.2015.10.015

Piccolotti, F. and Lovatelli, A. 2013. Construction and installation of hexagonal wooden cages for fish farming - A technical manual. FAO Fisheries and Aquaculture Technical Paper No. 576. Rome. Retrieved March 2021 from http:// www.fao.org/3/i3091e/i3091e00.htm

Ragbirsingh, Y. and De Souza, G. 2005. Site suitability for aquaculture development on the $\mathrm{Ca}$ roni River Basin, Trinidad West Indies using GIS. In: Proceedings of the Gulf and Caribbean Fisheries Institute, 56, pp. 661-673. Retrieved March, 2021 from http://aquaticcom- mons.org/13942/

Richard, J.U. and Ogba, C. 2016. Site selection analysis for suitable aquaculture fish pond in Andoni L.G.A. Rivers State, Nigeria. Int. J. Res. Granthaalayah, 4 (3): 219-232. https://doi. org/10.29121/granthaalayah.v4.i3.2016.2806

Ross, L.G., Falconer, L.L., Mendoza, A.C. and Palacious, C.A.M. 2010. Spatial modelling for freshwater cage location in the Presa Adolfo Mateos Lopez (E1 Infiernillo), Michoacan, Mexico. Aquacult. Res., 42: 797-807. https:// doi.org/10.1111/j.1365-2109.2010.02689.x

Salam, M.A., Ross, L.G. and Beveridge, C.M.M. 2002. A comparison of development opportunities for crab and shrimp aquaculture in southwestern Bangladesh, using GIS modelling. Aquaculture, 220. 477-494. https://doi. org/10.1016/S0044-8486(02)00619-1

Ssegane, H., Tollner, E. and Veverica, K. 2012. Geospatial Modeling of Site Suitability for PondBased Tilapia and Clarias Farming in Uganda. J. Appl. Aquacult., 24: 147-169. https://doi.org /10.1080/10454438.2012.663695

Thompson, O.A. and Mafimisebi, T.E. 2014. Profitability of selected ventures in catfish aquaculture in Ondo State, Nigeria. Fish Aquacult. J., 5 (2): $1-7$. 